\title{
A STUDY TO ASSESS THE EFFECTIVENESS OF STRUCTURED TEACHING PROGRAMME ON BREAST CANCER AND BREAST SELF-EXAMINATION AMONG THE WOMEN'S (35TO 50YR) AT RURAL AREA OF JEOLIKOTE, HALDWANI (UTTRAKHAND) Professor S. Hemalatha Principal Anbu College of Nursing Corresponding Email: hemapauls1@gmail.com
}

\section{ABSTRACT}

Introduction: Breast cancer is a uncontrolled growth of breast cells. The term "breast cancer" refers to a malignant tumour that has developed from cells in the breast.It is the most common invasive cancer and the second leading cause of cancer death in women's, exceeded only by lung cancer. Breast cancer is the most common cancer in India accounts for $14 \%$ of all cancer in women. In 2018, 1, 62,468 new cases and 87,090 deaths were reported for breast cancer in India i.e., for every 2 women newly diagnosed with breast cancer. One woman dies for it in India.

Material and Method: Pre-experimental design, Non-randomized sampling technique used total 50 women's (age 35 to 50) samples are selected rural area of joelikote, Uttarakhand. The data collected and analysed by using inferential statistics.

Results: The sample of this study comprise of 50 women. Collected data was analysed by using inferential statistics in the women. The findings of the study revealed that the pre-test mean value was 0.38 , mean and mean percentage was $38 \%$ and SD value was 11,497 and the post-test mean value was 0.67 , mean percentage was $67 \%$ and SD value was 19,562 according to this data analysis revealed that there is significant difference between pre-test value and post-test value ,according to the demographic value only age group was significant association with knowledge and there is non-significant association between religion, education, occupation, income, type of family, source of information.

Conclusion: Assessment of knowledge about breast cancer and breast self-examination of women's at rural area this helps to improve the knowledge about prevention of breast cancer.

Key Words: Breast cancer, Breast self-examination, knowledge

INTRODUCTION: Breast cancer, the most common non risk cancer, is now ranked as the first among all cancer diagnosed in women. In April 1998 the result of breast cancer prevention trial was released to the general public. Nursing interventions for the woman considering a risk reducing mastectomy include ensuring that the patient has information about referrals to plastic surgeons, genetic counsellors, psychological counsellor, there are about 1.7 million new cases and 522,000 deaths from breast cancer each year. Breast cancer is the most common cancer in women worldwide, and is the most common cause of cancer among women in most countries. In low- and middle-income countries reproductive patterns and the adoption of western 
lifestyles. Breast cancer is the most common cancer in India accounts for $14 \%$ of all cancer in women. In 2018, 1, 62,468 new cases and 87,090 deaths were reported for breast cancer in India i.e., for every 2 women newly diagnosed with breast cancer. One woman dies for it in India. According to estimation at least 17, 97,900 women in India may have breast cancer by 2020.Early detection of breast cancer by self-breast examination should be encouraged in developing countries to improve treatment results in breast cancer

\section{PROBLEMSTATEMENT-}

A study to assess the effectiveness of structured teaching program (STP) on breast cancer and breast self-examination among the women's (35 to $50 \mathrm{yr}$ ) at rural area of Jeolikote, Haldwani (Uttarakhand).

\section{OBJECTIVES}

- To assess the knowledge about breast cancer and breast selfexamination among women age group (35 to 50yr) in selective rural area.

- To assess the effectiveness of structured teaching program on knowledge regarding breast cancer and breast selfexamination among women in selected rural area.
- To find the association between the knowledge scores and selected demographic variables.

\section{Material and Method of Research design}

The research design refers to the researcher's overall plan for obtaining answer to the research questions. The research design used for the study is preexperimental design to assess the effectiveness of structure teaching programme on breast cancer and breast selfexamination among women at rural area of jeolikote, Uttrakhand

\section{RESEARCH SETTING:}

Setting refers to the area where the study is conducted it is the physical location and condition in which data collection takes place in the study. study was conducted in the rural area of Jeolikote, Uttarakhand

\section{ACCESSIBLE POPULATION:}

Accessible population is the aggregate of cases that confirms to designated criteria and also accessible for a study. The accessible population of present study were rural area females in selected area of Jeolikote, Uttarakhand.

\section{SAMPLING TECHNIQUE:}

The sample technique is a process of selecting a part of assigned population to represent the entire population. This study 
simple random sampling technique was used.

\section{SAMPLE AND SAMPLE SIZE:}

Sample is representative unit of target population. the samples of present study were selected females in selected rural area of Jeolikote, Uttarakhand.

SAMPLING CRITERIA:

Sampling criteria listed the characteristic's essential for membership in the target population. The following criteria were set to select the sample

\section{INCLUSIVE CRITERIA:}

01 . Rural women are in the village (35to 50 year)

02. Rural women are willing to participate in village

03. Rural women are having the knowledge of Hindi.

\section{EXCLUSIVE CRITERIA:}

1. Women's who are not present at the time of research

2. Women's are sick on the time

3. Women's who are physically disabled.

\section{DEVELOPMENT OF TOOL:}

The tools are the major aspect for assessing the knowledge level of the sample. It consists of two parts: PART 1: Consist of socio demographic variables
PART 2: Comprise of questionnaires regarding knowledge about breast cancer and breast self-examination.

\section{METHOD OF DATA COLLECTION:}

The various steps of strategies used for gathering, and analysis data in the research investigation one known as the method of the data collection. The investigator had collected the data after getting formal permission from the authority from the selected rural area, jeolikote, uttarakhand and approval was obtained to conduct the study. The participants were informed about the purpose of the study and written consent was taken from the participants. On an average each participants took 20 minutes to complete the questionnaire $\backslash$ tool. The investigator did not face any significant problem and the tool was found reliable.

\section{PLANS FOR DATA ANALYSIS:}

The data was analysed in term of objectives of the study using structured teaching program inferential statistics; the plan for data analysis is as follow:

- Organization of data in master sheet

- Analysis of the demographic characteristic of the sample

- Analysis of data by using structured teaching program statistics 
- Analysis data would be presented in the form of table and diagram.

\section{RESULT:}

- Over all comparison of pre-test and post-test mean, mean $\%$ and $\mathrm{SD}$ and paired ttest value of knowledge regarding breast cancer and breast self-examination.

\begin{tabular}{|c|c|c|c|c|c|c|c|}
\hline $\begin{array}{l}\text { s. } \\
\text { n. }\end{array}$ & $\begin{array}{l}\text { Compar } \\
\text { ison } \\
\text { Results }\end{array}$ & $\begin{array}{l}\text { Pre- } \\
\text { Test }\end{array}$ & $\begin{array}{l}\text { Post- } \\
\text { Test }\end{array}$ & $\begin{array}{l}\text { Pai } \\
\text { red } \\
\text { t- } \\
\text { Tes } \\
\text { t } \\
\text { Value }\end{array}$ & $\begin{array}{l}P \\
\text { Val } \\
\text { ue }\end{array}$ & $\begin{array}{l}d \\
\text { f }\end{array}$ & Inference \\
\hline 1 & Mean & 0.38 & 0.67 & \multirow{3}{*}{$\begin{array}{l}4.7 \\
99\end{array}$} & \multirow{3}{*}{$\begin{array}{l}2.7 \\
0\end{array}$} & \multirow{3}{*}{$\begin{array}{l}4 \\
9\end{array}$} & \multirow{3}{*}{$\begin{array}{l}\text { Signif } \\
\text { icant } \\
\mathrm{P}<4.799\end{array}$} \\
\hline 2 & Mean \% & $38 \%$ & $67 \%$ & & & & \\
\hline 3 & SD & $\begin{array}{l}11.4 \\
97\end{array}$ & $\begin{array}{l}19.5 \\
62\end{array}$ & & & & \\
\hline
\end{tabular}

The findings of the study revealed that the pre-test with mean value was 0.38 , mean percentage was $38 \%$ and $\mathrm{SD}$ was 11,497 and the post-test mean value was 0.67 , mean percentage was $67 \%$ and SD was 19,562. Paired t-test value 4.799. There is a significant difference between the pre-test and post-test, it shows that effectiveness of structure teaching programme on breast cancer and breast self-examination. The demographic data analysis revealed that there is significant association onlywith age group and other variables like religion, education, occupation, income, type of family, source of information were non-significant with pre-test scores. The study revealed that the women having less knowledge in pre-test after but after giving STP there is more knowledge about breast cancer and breast self-examination.

\section{REFERENCES}

01. K.R. Mehta Asian Pac cancer/breast cancerwww.ncbi,nlm.nin.gov/m/pub med.

02. Breast cancer statistics /breast cancerresearchfoundationhttp;//www.b crf.org>breast-cancer-statistics.

03. The changing face of breast cancer in India/scientific India www.scind .org> healththe-changing-face-of-breastcance r-in-India.

04. Shodhganga. Inflibnt.ac.i / jspui/bitstream/10603/183903/1/1\%20 introduction.pdf.

05. Shalini, divya Varghese and Malathi Nayak awareness and impact of education on breast self-examination among women.

06. Nightingale Nursing Time journal Vol XIII No.1 April 2017 (41-44) prasannaDeshpande \& Rudreshi Sanna shivannanvar.

07. MEI Asmar, A Bechnak, J Fares Asian Pacific journal 2018 -ncbinlm.nih.gov.

08. http:dx.doi.org/10.18203/23946040.ijc mph 20174856 Rakesh Singh, 
AlkaTuruk on study to assess the knowledge regarding breast cancer and practices of breast selfexamination among women in urban area.

09. S Madhukumar, UR Thambiran, BhavyaBasavaraju, Mayur R Bedadala Journal of family medicine and primary care 6(3), 487, 2017 -ncibnlm,nih.gov.

10. S A Rabbani, H Mustasem, RA Naser, Y Hussein-JAPPL Journal of applied pharmaceutical science Vol 7(02) PP. 142-146, Feruary 2017 available online at http://www.japsonline.com Article in oman medical Journal 31(2): 129-134 on breast cancer knowledge and breast self-examination practices among female.

11. Identification of breast cancer susceptibility gene BACA2: nature.com

12. Jeanemandelbhatt, Catherine Armetta /Breast cancer in India /www.NcbI .ntlm.nin.gov/m/pubmedP somdatta, NB aridalyne. India journal of cancer, 2008. India/cancer.com. 